FINANCIAL: Jurnal Akuntansi

Published by Program Studi Akuntansi STIE Sultan Agung

Volume 5-Nomor 2, Desember 2019, (HIm 30-39)

ISSN-P: 2502-4574, ISSN-E: 2686-2581

Available online at: https://financial.ac.id/index.php/financial

\title{
PERBANDINGAN KINERJA KEUANGAN SEBELUM DAN SESUDAH AKUISISI PADA PT FIRST MEDIA, TbK YANG TERDAFTAR DI BURSA EFEK INDONESIA
}

\author{
Nur Safitri ${ }^{1)^{*}}$, Supitriyani' ${ }^{2)}$, Debi Eka Putri ${ }^{3)}$, Khairul Azwar ${ }^{4)}$ \\ ${ }^{1,2,3,4}$ Program Studi Akuntansi, STIE Sultan Agung, Pematangsiantar, Sumatera Utara, Indonesia \\ *Email: 1'syahfitri.hsb18@gmail.com, 2supitriyani@ stiesultanagung.ac.id, \\ ${ }^{3}$ debiekaputri@stiesultanagung.ac.id, ${ }^{4}$ khairulazwar@stiesultanagung.ac.id
}

\begin{abstract}
Abstrak
Tujuan dari penelitian ini adalah untuk mengetahui gambaran kinerja keuangan sebelum dan sesudah akuisisi pada PT First Media, Tbk yang terdaftar di Bursa Efek Indonesia dan untuk mengetahui faktor-faktor yang menyebabkan perbedaan kinerja keuangan sebelum dan sesudah akuisisi pada PT First Media, Tbk yang terdaftar di Bursa Efek Indonesia. Penelitian ini dilakukan dengan menggunakan metode analisis deskriptif kualitatif, analisis komparatif dan analisis induktif. Jenis data yang digunakan dalam penelitian ini adalah data kualitatif dan kuantitatif. Sumber data yang digunakan adalah data sekunder. Hasil penelitian ini disimpulkan bahwa Kinerja keuangan perusahaan sebelum akuisisi ditinjau dari Current Ratio (CR), Debt Ratio (DR), dan Debt to Equity Ratio (DER) berfluktuasi dan cenderung menurun, sedangkan nilai Total Asset Turnover (TATO) berfluktuasi dan cenderung meningkat, untuk nilai Return on Asset (ROA), Return on Equity (ROE), dan Net Profit Margin (NPM) cenderung meningkat. Kinerja keuangan perusahaan sesudah akuisisi ditinjau dari Current Ratio (CR) berfluktuasi dan cenderung menurun, sedangkan nilai Debt Ratio (DR) dan Debt to Equity Ratio (DER) cenderung meningkat, untuk nilai Total Asset Turnover (TATO) mengalami fluktuasi dan cenderung meningkat. Sedangkan nilai Return on Asset (ROA), Return on Equity (ROE), dan Net Profit Margin (NPM) mengalami penurunan. Faktor kas dan setara kas, piutang kepada pihak ketiga, investasi pada entitas asosiasi, aset tak berwujud, aset pajak tangguhan, utang usaha kepada pihak ketiga, utang bank dan lembaga keuangan jangka pendek, utang bank dan lembaga keuangan jangka panjang, beban akrual, saldo laba, beban layanan, beban keuangan, dan pendapatan menyebabkan perbedaan kinerja keuangan sebelum dan sesudah akuisisi.
\end{abstract}

Kata kunci: Akuisisi, Kinerja Keuangan

\section{COMPARISON OF FINANCIAL PERFORMANCE BEFORE AND AFTER ACQUISITION IN PT FIRST MEDIA, TbK LISTED IN INDONESIA STOCK EXCHANGE \\ Abstract}

The purpose of this research are: To determine the description of financial performance before and after acquisition at PT First Media, Tbk. To determine the factors that lead difference of financial performance before and after acquisition at PT First Media, Tbk. The research was done by using descriptive analysis method, analysis comparative, and analysis inductive. The types of data used in this research are qualitative data and quantitative data. Source of data used is secondary data.The result of this research can be conclude as: The corporate financial performance before acquisition in review from Current Ratio (CR), Debt Ratio (DR), and Debt to Equity Ratio (DER) is fluctuate and tend decrease, while the value of the Total Asset Turnover (TATO) is fluctuate and tend increase, the value of Return on Asset (ROA), Return on Equity (ROE), and Net Profit Margin $(N P M)$ tend increase. The corporate financial performance after acquisition in review form Current Ratio (CR) is fluctuate and tend decrease, while the value of Debt Ratio (DR) and Debt to Equity Ratio (DER) tend increase, the value of Total Asset Turnover (TATO) is fluctuate and tend increase. While the value of Return on Asset (ROA), Return on Equity (ROE), and Net Profit Margin (NPM) are decrease. Factors of cash and cash equivalents, account receivable to third parties, investment in associates, intangible assets, deferred tax assets, account payable to third parties, borrowing from banks and othe financial institutions short term, borrowing from banks and othe financial institutions long term, accrued expenses, retained earnings, cost of services, finance cost, and revenues that caused the difference in financial performance before and after acquisition. Keywords: Acquisition, Financial Performance

Article History: Received: 30 Sep 2019 Revised: 1 Okt 2019 Accepted: 4 Nop 2019 


\section{PENDAHULUAN}

Era revolusi industri 4.0 tengah memasuki dunia. Hal ini ditandai dengan meningkatnya konektivitas, interaksi, dan batas antara mesin, manusia, dan sumber daya lainnya yang semakin berpusat pada teknologi informasi dan komunikasi (Https://www.kompasiana.com). Sejalan dengan hal tersebut, diperlukan strategi perusahaan yang tepat baik secara internal maupun external. Strategi internal dapat dilakukan dengan menganalisis kinerja keuangan perusahaan guna menetapkan langkah-langkah perbaikan dan efisiensi untuk periode selanjutnya. Sedangkan strategi external dapat dilakukan dengan melakukan penggabungan usaha. Salah satu jenis penggabungan usaha adalah akuisisi.

Berhasil atau tidaknya proses akuisisi suatu perusahaan, tergantung pada kinerja keuangan perusahaan tersebut. Kinerja keuangan merupakan dasar penilaian mengenai kondisi keuangan yang menunjukkan kemampuan perusahaan dalam mengelola asetnya. Perubahan kinerja keuangan perusahaan sebelum dan sesudah melakukan akuisisi dapat dinilai melalui analisis terhadap laporan keuangan dengan menggunakan rasio keuangan.

Analisis rasio keuangan yang digunakan adalah rasio profiitabilitas. Rasio ini digunakan untuk melihat kemampuan perusahaan menghasilkan laba dengan menggunakan seluruh modal yang dimilikinya. Dalam penelitian ini, rasio profitabilitas yang digunakan adalah Return on Asset (ROA), Return on Equity (ROE), dan Net Profit Margin (NPM).

PT First Media, Tbk (KBLV) merupakan perusahaan yang termasuk dalam sektor perdagangan, jasa dan investasi yang berada di Jakarta dan didirikan pada tahun 1994 dengan nama Broadband Multimedia.
Produk perusahaan ini berupa layanan TV kabel, internet pita lebar dan komunikasi data yang secara keseluruhan dikenal dengan nama triple play. Pada tahun 2015, PT First Media, Tbk mengakuisisi PT Mitra Mandiri Mantap yang merupakan induk usaha dari PT Internux, perusahaan penyedia layanan broadband wireless access dengan merk dagang BOLT. Berikut disajikan gambaran rasio profitabilitas dengan menggunakan Return On Asset (ROA), Return On Equity (ROE), dan Net Profit Margin (NPM) pada PT First Media, Tbk yang terdaftar di Bursa Efek Indonesia.

Tabel 1

Gambaran Profitabilitas pada PT First Media, Tbk yang Terdaftar di Bursa Efek Indonesia Periode 2012-2017

\begin{tabular}{|c|c|c|c|}
\hline Tahun & $\begin{array}{c}\text { ROA } \\
\text { (Kali) }\end{array}$ & $\begin{array}{c}\text { ROE } \\
\text { (Kali) }\end{array}$ & $\begin{array}{c}\text { NPM } \\
\text { (Kali) }\end{array}$ \\
\hline 2012 & 0,0024 & 0,0043 & 0,0079 \\
\hline 2013 & 0,0038 & 0,0082 & 0,0114 \\
\hline 2014 & 0,6089 & 0,8421 & 3,8944 \\
\hline $\begin{array}{c}\text { Rata-rata } \\
\text { Sebelum } \\
\text { Akuisisi }\end{array}$ & $\mathbf{0 , 2 1}$ & $\mathbf{0 , 2 8}$ & $\mathbf{1 , 3 0}$ \\
\hline 2015 & $-0,1104$ & $-0,1788$ & $-1,4240$ \\
\hline 2016 & $-0,1242$ & $-0,2193$ & $-1,2133$ \\
\hline 2017 & $-0,1237$ & $-0,2636$ & $-1,5216$ \\
\hline $\begin{array}{c}\text { Rata-rata } \\
\text { Sesudah } \\
\text { Akuisisi }\end{array}$ & $\mathbf{- 0 , 1 2}$ & $\mathbf{- 0 , 2 2}$ & $\mathbf{- 1 , 3 9}$ \\
\hline
\end{tabular}

Sumber: Laporan Keuangan PT First Media,Tbk (Data Diolah), 2019

Dari Tabel 1 dapat dilihat bahwa gambaran profitabilitas sebelum akuisisi jauh lebih baik daripada sesudah akuisisi. Rata-rata nilai Return On Asset (ROA), Return On Equity (ROE) dan Net Profit Margin (NPM) PT First Media, Tbk sebelum akuisisi masing-masing sebesar 0,21 kali, 0,28 kali, dan 1,30 kali. Sedangkan sesudah akuisisi, nilai rata-rata Return On Asset (ROA), Return On Equity (ROE) dan Net Profit Margin (NPM) pada PT First Media, Tbk mengalami penurunan yang cukup signifikan, yaitu sebesar $-0,12$ kali, 0,22 kali, dan -1,39 kali. Hal ini tidak sejalan 
dengan teori yang dikemukakan oleh (Moin, 2010), "segera setelah akuisisi, ukuran perusahaan dengan sendirinya bertambah besar karena aset, kewajiban dan ekuitas perusahaan digabung bersama. Jika size bertambah besar ditambah dengan sinergi yang dihasilkan dari gabungan aktivitasaktivitas simultan, maka laba perusahaan juga semakin meningkat. Maka, kinerja perusahaan pasca akuisisi seharusnya semakin baik dibandingkan dengan sebelum akuisisi”.

Rumusan masalah dalam penelitian ini adalah bagaimana gambaran kinerja keuangan sebelum dan sesudah akuisisi pada PT First Media, Tbk yang terdaftar di Bursa Efek Indonesia serta faktor-faktor apa yang menyebabkan perbedaan kinerja keuangan sebelum dan sesudah akuisisi pada PT First Media, Tbk yang terdaftar di Bursa Efek Indonesia. Tujuan penelitian adalah untuk mengetahui gambaran kinerja keuangan sebelum dan sesudah akuisisi pada PT First Media, Tbk yang terdaftar di Bursa Efek Indonesia serta mengetahui faktor-faktor yang menyebabkan perbedaan kinerja keuangan sebelum dan sesudah akuisisi pada PT First Media, Tbk yang terdaftar di Bursa Efek Indonesia

\section{LANDASAN TEORI}

Akuntansi dapat diartikan sebagai proses pencatatan, penggolongan, peringkasan, pelaporan dan penganalisaan data keuangan suatu organisasi (Mursyidi, 2010). Salah satu tujuan akuntansi adalah memberikan informasi keuangan yang dapat dipercaya mengenai sumber-sumber ekonomi dan kewajiban serta modal perusahaan (Rudianto, 2012).

Laporan keuangan adalah hasil proses pencatatan akuntansi keuangan. Laporan keuangan itu berisi informasi tentang Copyright (C) 2019, FINANCIAL: Jurnal Akuntansi prestasi perusahaan dibidang keuangan pada masa lampau. Laporan tersebut dibuat untuk memberikan gambaran / laporan kemajuan secara periodik oleh pihak manajemen yang bersangkutan. (Ramadhan dan La Ode, 2016).

Laporan keuangan perlu dimengerti dan dipahami oleh berbagi pihak, sehingga diperlukan analisis laporan keuangan. Analisis laporan keuangan dapat digunakan untuk mengevaluasi kondisi keuangan perusahaan di masa lalu, masa sekarang dan masa yang akan datang. Analisis terhadap laporan keuangan, sangatlah penting bagi seorang analis untuk mengetahui dan mengenal bentuk ataupun prinsip penyusunan laporan keuangan serta masalah-masalah yang diperkirakan timbul dalam penyusunan laporan keuangan (Pongoh, 2013).

Dari segi ekonomi untuk menilai suatu perusahaan baik atau buruk dapat dilihat berdasarkan kinerja keuangan, karena kinerja keuangan menggambarkan kondisi keuangan suatu perusahaan. Kinerja keuangan merupakan hasil nyata (prestasi) yang dapat dicapai dari proses pengambilalihan keputusan oleh manajemen perusahaan untuk menunjang dicapainya hasil positif dalam hal keuangan (Aprilita, Rina, dan Aspahani, 2013).

Pengukuran kinerja mengukur tingkat keberhasilan keputusan yang diambil oleh manajemen. Kinerja keuangan perusahaan menjadi alat ukur bagi investor untuk menilai suatu perusahaan sehingga perusahaan akan menjaga kondisi keuangan dalam posisi yang aman. Perubahan kinerja keuangan perusahaan sebelum dan sesudah melakukan akuisisi dapat dilihat melalui analisis terhadap laporan keuangan dengan menggunakan rasio keuangan. (Setiawan, 2013). 
Salah satu strategi ekspansi perusahaan adalah dengan penggabungan usaha untuk mendapatkan pengendalian atas aktiva atau operasional perusahaanperusahaan yang bergabung. Salah satu jenis penggabungan usaha adalah akuisisi. Akuisisi adalah pengambilalihan seluruh atau sebagian besar saham perusahaan yang mengakibatkan beralihnya pengendalian terhadap perusahaan yang bersangkutan. Perusahaan melakukan merger dan akuisisi harapannya agar kinerja keuangan perusahaan yang bergabung dapat meningkat (Novaliza dan Atik, 2013).

Rasio keuangan berisi informasi mengenai hubungan antara satu pos dengan pos lainnya dalam laporan keuangan. Analisis rasio keuangan adalah perbandingan antara pos-pos tertentu dalam laporan keuangan dengan pos lain yang memiliki hubungan yang signifikan (Ottay dan Stanly, 2015). Rasio keuangan dirancang untuk membantu dalam mengevaluasi laporan keuangan. Jenis-jenis rasio keuangan (Brigham dan Joel, 2012). Rasio yang dimaksud terdiri atas:

1. Rasio Likuiditas

Rasio ini terdiri dari:

1) Rasio Lancar

$$
\text { Rasio Lancar }=\frac{\text { Aset Lancar }}{\text { Kewajiban Lancar }}
$$

2) Rasio Cepat

$$
\text { Rasio Cepat }=\frac{\text { Aset Lancar }- \text { Persediaan }}{\text { Kewajiban Lancar }}
$$

2. Rasio Manajemen Utang

Rasio ini terdiri dari:

1) Debt Ratio

$$
\text { Rasio Utang }=\frac{\text { Total Utang }}{\text { Total Aset }}
$$

2) Time Interest Earned (TIE)

$$
\begin{aligned}
& \text { Rasio Kelipatan Pembayaran Bunga } \\
& =\frac{\text { EBIT }}{\text { Beban Bunga }}
\end{aligned}
$$

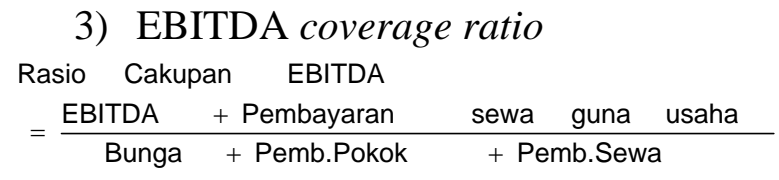

3. Rasio Manajemen Aset

Rasio ini terdiri dari:

1) Rasio Perputaran Persediaan (Inventory Turnover Ratio)

Perputaran Persediaan $=\frac{\text { Penjualan }}{\text { Persediaan }}$

2) Days Sales Outstanding (DSO)

$$
\text { DSO }=\frac{\text { Piutang }}{\text { Penjualan Tahunan } / 365}
$$

3) Rasio Perputaran Aset Tetap (Fixed Assets Turnover Ratio)

Perputaran Aset Tetap $=\frac{\text { Penjualan }}{\text { Aset Tetap Bersih }}$

4) Perputaran Total Aset (Total Assets Turnover Ratio)

Perputaran Total Aset $=\frac{\text { Penjualan }}{\text { Total Aset }}$

4. Rasio Profitabilitas

Rasio terdiri dari:

1) Margin laba atas penjualan

Margin Laba atas Penjualan $=\frac{\text { Laba Bersih }}{\text { Penjualan }}$

2) Pengembalian atas total aset (ROA)

$$
\text { ROA }=\frac{\text { Laba Bersih }}{\text { Total Aset }}
$$

3) Rasio Kemampuan Dasar untuk Menghasilkan Laba (BEP)

$$
\mathrm{BEP}=\frac{\mathrm{EBIT}}{\text { Total Aset }}
$$

4) Pengembalian Ekuitas Biasa (ROE)

$$
\mathrm{ROE}=\frac{\text { Laba Bersih }}{\text { Ekuitas Biasa }}
$$

Kinerja keuangan mencerminkan prestasi kerja perusahaan dalam periode tertentu. Kinerja keuangan sangat penting dicapai oleh setiap perusahaan, karena kinerja keuangan akan berdampak kepada nilai perusahaan. Berbagai strategi dapat dilakukan perusahaan untuk memaksimalkan kinerja keuangan 
perusahaan. Segera setelah akuisisi, ukuran perusahaan dengan sendirinya bertambah besar karena aset, kewajiban dan ekuitas perusahaan digabung bersama. Jika size bertambah besar ditambah dengan sinergi yang dihasilkan dari gabungan aktivitasaktivitas simultan, maka laba perusahaan juga semakin meningkat. Maka, kinerja perusahaan pasca akuisisi seharusnya semakin baik dibandingkan dengan sebelum akuisisi (Moin, 2010). Penelitian yang dilakukan oleh Melindhar (2015) menyatakan bahwa kinerja keuangan perusahaan sesudah akuisisi mengalami peningkatan yang cukup signifikan namun juga mengalami penurunan dibandingkan sebelum melakukan akuisisi.

\section{METODE}

Dalam penelitian ini, objek penelitian yang penulis gunakan adalah laporan keuangan PT First Media, Tbk selama 6 tahun terakhir yaitu dari tahun 2012 sampai dengan 2017 yang telah diaudit. Desain penelitian yang digunakan adalah penelitian kepustakaan (library research) yang menggunakan data sekunder dengan cara mengakses dari situs http://www.idx.co.id. Ruang lingkup penelitian adalah laporan keuangan PT First Media, Tbk periode 2012-2017. Variabel yang diteliti adalah akuisisi (X) dan kinerja keuangan (Y) pada PT First Media, Tbk dari tahun 2012 sampai dengan 2017 dengan menggunakan alat ukur rasio keuangan yang terdiri dari proksi current ratio sebagai indikator likuiditas, proksi debt ratio dan debt to equity ratio sebagai indikator manajemen utang, proksi total asset turn over sebagai indikator aktivitas, proksi return on asset, return on equity dan net profit margin sebagai indikator profitabilitas Dalam penelitian ini, penulis menggunakan data kualitatif dan data kuantitatif. Teknik Copyright (C) 2019, FINANCIAL: Jurnal Akuntansi pengumpulan data adalah teknik dokumentasi dengan cara mencari data dari buku, jurnal akuntansi, surat kabar, dan dokumen-dokumen yang terkait dengan penelitian ini serta media internet dengan cara mengunduh laporan keuangan melalui situs resmi Bursa Efek Indonesia dan www.firstmedia.com yang merupakan website resmi PT First Media, Tbk. Teknik analisis data yang digunakan adalah analisis deskriptif kualitatif, teknik analisis komparatif dan analisis induktif.

\section{HASIL DAN PEMBAHASAN}

Dalam penelitian ini analisis rasio keuangan PT Media First, Tbk terdiri dari beberapa perhitungan rasio yang terdiri dari rasio likuiditas, rasio manajemen utang, rasio manajemen aset, dan rasio profitibalitas yang keseluruhan dari rasio tersebut digunakan untuk mengukur kinerja keuangan PT First Media, Tbk.

1. Analisis Rasio Likuiditas sebelum dan sesudah akuisisi PT First Media, Tbk

Rasio likuiditas sebelum dan sesudah akuisisi pada PT First Media, Tbk dapat dilihat melalui Current Ratio (CR) pada Tabel 2.

Tabel 2

Current Ratio (CR) PT First Media, Tbk yang Terdaftar di Bursa Efek Indonesia Sebelum dan Sesudah Akuisisi (dalam jutaan)

\begin{tabular}{|c|c|c|c|}
\hline Tahun & $\begin{array}{c}\text { Aset } \\
\text { Lancar } \\
\text { (Rp) }\end{array}$ & $\begin{array}{c}\text { Hutang } \\
\text { Jangka } \\
\text { Pendek } \\
\text { (Rp) }\end{array}$ & CR (Kali) \\
\hline 2012 & 1.138 .314 & 828.543 & 1,3739 \\
\hline 2013 & 1.223 .581 & 1.606 .207 & 0,7618 \\
\hline 2014 & 1.479 .197 & 1.468 .904 & 1,0070 \\
\hline Rata-Rata Sebelum Akuisisi (2012- & $\mathbf{1 , 0 4 7 6}$ \\
\hline 2015 & 2014) \\
\hline 2016 & 1.206.209 & 3.121 .755 & 0,3864 \\
\hline 2017 & 871.313 & 4.110 .888 & 0,2363 \\
\hline Rata-Rata Sesudah Akuisisi (2015- & $\mathbf{0 , 2 7 0 6}$ \\
\hline \multicolumn{3}{|c|}{ 2017) } \\
\hline
\end{tabular}

Sumber: Laporan Keuangan PT First Media, Tbk (Data Diolah), 2019 
Dari Tabel 2 dapat dilihat bahwa sebelum akuisisi nilai rata-rata Current Ratio (CR) adalah sebesar 1,0476 kali, namun sesudah akuisisi nilai rata-rata Current Ratio (CR) turun sebesar 0,7770 kali menjadi 0,2706 kali. Kondisi ini menunjukkan bahwa kinerja keuangan perusahaan lebih baik sebelum perusahaan melakukan akuisisi. Nilai rata-rata Current Ratio (CR) sesudah akuisisi mengalami penurunan dari nilai rata-rata Current Ratio (CR) sebelum akuisisi. Penurunan ini disebabkan oleh jumlah aset lancar yang mengalami penurunan adalah kas dan setara kas dan piutang kepada pihak ketiga. Sedangkan, liabilitas jangka pendek yang mengalami peningkatan adalah utang usaha kepada pihak ketiga, beban akrual, dan utang bank dan lembaga keuangan jangka pendek.

2. Analisis Rasio Manajemen utang sebelum dan sesudah akuisisi pada PT First Media, Tbk

Rasio manajemen utang sebelum dan sesudah akuisisi pada PT First Media, Tbk dapat dilihat sebagai berikut.

1) Debt Ratio (DR)

Berikut ini disajikan gambaran Debt Ratio (DR) pada Tabel 3.

Tabel 3

Debt Ratio (DR) PT First Media, Tbk yang Terdaftar di Bursa Efek Indonesia Sebelum dan Sesudah Akuisisi (dalam jutaan)

\begin{tabular}{|c|c|c|c|}
\hline \multirow{2}{*}{ Tahun } & $\begin{array}{c}\text { Total } \\
\text { Hutang } \\
\text { (Rp) }\end{array}$ & $\begin{array}{c}\text { Total } \\
\text { Aset (Rp) }\end{array}$ & DR (Kali) \\
\hline 2012 & 1.889 .975 & 4.306 .576 & 0,4389 \\
\hline 2013 & 2.805 .711 & 5.242 .465 & 0,5352 \\
\hline 2014 & 3.586 .560 & 12.951 .946 & 0,2769 \\
\hline Rata-Rata Sebelum Akuisisi (2012- & $\mathbf{0 , 4 1 7 0}$ \\
\hline 2015 & 2014) & 13.711 .988 & 0,3827 \\
\hline 2016 & 5.540 .481 & 12.779 .523 & 0,4335 \\
\hline 2017 & 6.417 .462 & 12.089 .473 & 0,5308 \\
\hline Rata-Rata Sesudah Akuisisi (2015- & $\mathbf{0 , 4 4 9 0}$ \\
\hline
\end{tabular}

Sumber: Laporan Keuangan PT First Media, Tbk (Data Diolah), 2019
Dari Tabel 3 dapat dilihat bahwa nilai rata-rata Debt Ratio (DR) sebelum akuisisi adalah sebesar 0,4170 kali dan mengalami peningkatan sesudah akuisisi sebesar 0,0320 kali menjadi 0,4490 kali. Nilai ratarata Debt Ratio (DR) sesudah akuisisi mengalami peningkatan dari nilai rata-rata Debt Ratio (DR) sebelum akuisisi. Kondisi ini menunjukkan bahwa kinerja keuangan perusahaan lebih baik sebelum perusahaan melakukan akuisisi Peningkatan ini disebabkan oleh total liabilitas yang meningkat cukup signifikan, yaitu utang kepada pihak ketiga, utang bank dan lembaga keuangan baik jangka pendek maupun jangka panjang, serta beban akrual.

2) Debt to Equity Ratio (DER)

Berikut ini disajikan gambaran Debt to Equity Ratio (DER) pada Tabel 4.

\section{Tabel 4}

Debt to Equity Ratio (DER) PT First Media, Tbk yang Terdaftar di Bursa Efek Indonesia Sebelum dan Sesudah Akuisisi (dalam jutaan)

\begin{tabular}{|c|c|c|c|}
\hline Tahun & $\begin{array}{c}\text { Total } \\
\text { Hutang } \\
\text { (Rp) }\end{array}$ & $\begin{array}{l}\text { Ekuitas } \\
\text { (Rp) }\end{array}$ & DER (Kali) \\
\hline 2012 & 1.889 .975 & 2.416 .601 & 0,7821 \\
\hline 2013 & 2.805 .711 & 2.436 .754 & 1,1514 \\
\hline 2014 & 3.586 .560 & 9.365 .386 & 0,3830 \\
\hline \multicolumn{3}{|c|}{$\begin{array}{l}\text { Rata-Rata Sebelum Akuisisi (2012- } \\
\text { 2014) }\end{array}$} & 0,7722 \\
\hline 2015 & 5.247 .517 & 8.464 .471 & 0,6199 \\
\hline 2016 & 5.540 .481 & 7.239 .042 & 0,7654 \\
\hline 2017 & 6.417 .462 & 5.672 .011 & 1,1314 \\
\hline \multicolumn{3}{|c|}{$\begin{array}{c}\text { Rata-Rata Sesudah Akuisisi (2015- } \\
\text { 2017) }\end{array}$} & 0,8389 \\
\hline
\end{tabular}

Sumber: Laporan Keuangan PT First Media, Tbk (Data Diolah), 2019

Dari Tabel 4 dapat dilihat bahwa nilai rata-rata Debt to Equity Ratio (DER) sebelum akuisisi adalah sebesar 0,7722 kali dan mengalami peningkatan sesudah akuisisi sebesar 0,0668 kali menjadi 0,8389 kali. Kondisi ini menunjukkan bahwa kinerja keuangan perusahaan lebih baik sebelum perusahaan melakukan akuisisi. Nilai rata-rata Debt to Equity Ratio (DER) sesudah akuisisi mengalami peningkatan 
dari nilai rata-rata Debt to Equity Ratio (DER) sebelum akuisisi. Peningkatan ini disebabkan oleh total liabilitas yang meningkat cukup signifikan, namun ekuitas mengalami penurunan. Ekuitas yang menurun disebabkan karena saldo laba perusahaan.

3. Analisis Rasio Manajemen Aset sebelum dan sesudah akuisisi pada PT First Media, Tbk

Rasio manajemen aset sebelum dan sesudah akuisisi pada PT First Media, Tbk dapat dilihat pada Tabel 5.

Tabel 5

Total Asset Turnover (TATO) PT First Media, Tbk yang Terdaftar di Bursa Efek Indonesia Sebelum dan Sesudah Akuisisi (dalam jutaan)

\begin{tabular}{|c|c|c|c|}
\hline Tahun & $\begin{array}{c}\text { Pendapatan } \\
\text { (Rp) }\end{array}$ & $\begin{array}{c}\text { Total } \\
\text { Aset (Rp) }\end{array}$ & TATO (Kali) \\
\hline 2012 & 1.322 .439 & 4.306 .576 & 0,3071 \\
\hline 2013 & 1.754 .102 & 5.242 .465 & 0,3346 \\
\hline 2014 & 2.024 .973 & 12.951 .946 & 0,1563 \\
\hline Rata-Rata Sebelum Akuisisi (2012- & $\mathbf{0 , 2 6 6 0}$ \\
\hline 2015 & 1.062 .980 & 13.711 .988 & 0,0775 \\
\hline 2016 & 1.308 .250 & 12.779 .523 & 0,1024 \\
\hline 2017 & 982.463 & 12.089 .473 & 0,0813 \\
\hline Rata-Rata Sesudah Akuisisi (2015- & $\mathbf{0 , 0 8 7 1}$ \\
\hline
\end{tabular}

Sumber: Laporan Keuangan PT First Media, Tbk

(Data Diolah), 2019

Dari Tabel 5 dapat dilihat bahwa nilai rata-rata Total Assets Turn Over (TATO) sebelum akuisisi adalah sebesar 0,2660 kali dan mengalami penurunan sesudah akuisisi sebesar 0,1790 kali menjadi 0,0871 kali. Hal ini disebabkan karena investasi pada entitas asosiasi, aset tak berwujud, dan aset pajak tangguhan mengalami kenaikan yang cukup signifikan sesudah akuisisi sedangkan pendapatan mengalami penurunan.

4. Analisis Rasio Profitabilitas sebelum dan sesudah akuisisi pada PT First Media, Tbk
Rasio profitabilitas sebelum dan sesudah akuisisi pada PT First Media, Tbk dapat dilihat sebagai berikut.

1) Return on Asset (ROA)

Berikut ini disajikan gambaran Return on Asset (ROA) pada Tabel 6.

Tabel 6

Return on Assets (ROA) PT First Media, Tbk yang Terdaftar di Bursa Efek Indonesia Sebelum dan Sesudah Akuisisi

\begin{tabular}{|c|c|c|c|}
\hline Tahun & $\begin{array}{c}\text { Laba } \\
\text { Bersih } \\
\text { Setelah } \\
\text { Pajak (Rp) }\end{array}$ & $\begin{array}{c}\text { Total } \\
\text { Aset (Rp) }\end{array}$ & ROA (Kali) \\
\hline 2012 & 10.470 & 4.306 .576 & 0,0024 \\
\hline 2013 & 19.937 & 5.242 .465 & 0,0038 \\
\hline 2014 & 7.886 .152 & 12.951 .946 & 0,6089 \\
\hline Rata-Rata Sebelum Akuisisi (2012- & $\mathbf{0 , 2 0 5 0}$ \\
\hline 2015 & -1.513 .714 & 13.711 .988 & $-0,1104$ \\
\hline 2016 & -1.587 .310 & 12.779 .523 & $-0,1242$ \\
\hline 2017 & -1.494 .888 & 12.089 .473 & $-0,1237$ \\
\hline Rata-Rata Sesudah Akuisisi (2015- & $\mathbf{- 0 , 1 1 9 4}$ \\
\hline \multicolumn{3}{|c|}{ 2017) } \\
\hline
\end{tabular}

Sumber: Laporan Keuangan PT First Media, Tbk (Data Diolah), 2019

Dari Tabel 6 dapat dilihat bahwa nilai rata-rata Return on Asset (ROA) sebelum akuisisi adalah sebesar 0,2050 kali dan mengalami penurunan sesudah akuisisi sebesar 0,3245 kali menjadi -0,1194 kali. Kondisi ini menunjukkan bahwa kinerja keuangan perusahaan lebih baik sebelum perusahaan melakukan akuisisi. Penurunan ini disebabkan oleh kerugian yang dialami perusahaan. Beban layanan dan beban keuangan mengalami peningkatan yang cukup signifikan, namun pendapatan perusahaan menurun. Investasi pada entitas asosiasi, aset tak berwujud, dan aset pajak tangguhan mengalami kenaikan yang cukup signifikan sesudah akuisisi.

2) Return on Equity (ROE)

Berikut ini disajikan gambaran Return on Equity (ROE) pada Tabel 7.

Tabel 7

Return on Equity (ROE) PT First Media, Tbk yang Terdaftar di Bursa Efek Indonesia Sebelum dan Sesudah Akuisisi 


\begin{tabular}{|c|c|c|c|}
\hline Tahun & $\begin{array}{c}\text { Laba } \\
\text { Bersih } \\
\text { Setelah } \\
\text { Pajak (Rp) }\end{array}$ & $\begin{array}{c}\text { Ekuitas } \\
(\text { Rp) }\end{array}$ & ROE (Kali) \\
\hline 2012 & 10.470 & 2.416 .601 & 0,0043 \\
\hline 2013 & 19.937 & 2.436 .754 & 0,0082 \\
\hline 2014 & 7.886 .152 & 9.365 .386 & 0,8421 \\
\hline \multicolumn{3}{|c|}{ Rata-Rata Sebelum Akuisisi } & $\mathbf{0 , 2 8 4 9}$ \\
\hline 2015 & -1.513 .714 & 8.464 .471 & $-0,1788$ \\
\hline 2016 & -1.587 .310 & 7.239 .042 & $-0,2193$ \\
\hline 2017 & -1.494 .888 & 5.672 .011 & $-0,2636$ \\
\hline Rata-Rata Sesudah Akuisisi (2015- & $\mathbf{- 0 , 2 2 0 6}$ \\
\hline \multicolumn{3}{|c|}{$\mathbf{2 0 1 7 )}$} \\
\hline
\end{tabular}

Sumber: Laporan Keuangan PT First Media, Tbk (Data Diolah), 2019

Dari Tabel 7 dapat dilihat bahwa nilai rata-rata Return on Equity (ROE) sebelum akuisisi adalah sebesar 0,2849 kali dan mengalami penurunan sesudah akuisisi sebesar 0,5054 kali menjadi -0,2206 kali. Nilai rata-rata Return on Equity (ROE) sesudah akuisisi mengalami penurunan dari nilai rata-rata Return on Equity (ROE) sebelum akuisisi. Penurunan ini disebabkan oleh kerugian yang dialami perusahaan diikuti dengan menurunnya ekuitas perusahaan. Beban layanan dan beban keuangan mengalami peningkatan yang cukup signifikan, namun pendapatan perusahaan menurun yang menyebabkan saldo laba ikut menurun..

\section{3) Net Profit Margin (NPM)}

Berikut ini disajikan gambaran $\mathrm{Net}$ Profit Margin (NPM) pada Tabel 8.

\section{Tabel 8}

Net Profit Margin (NPM) PT First Media, Tbk yang Terdaftar di Bursa Efek Indonesia Sebelum dan Sesudah Akuisisi

\begin{tabular}{|c|c|c|c|}
\hline Tahun & $\begin{array}{c}\text { Laba } \\
\text { Bersih } \\
\text { Setelah } \\
\text { Pajak (Rp) }\end{array}$ & $\begin{array}{l}\text { Pendapatan } \\
\quad(\mathbf{R p})\end{array}$ & NPM (Kali) \\
\hline 2012 & 10.470 & 1.322 .439 & 0,0079 \\
\hline 2013 & 19.937 & 1.754 .102 & 0,0114 \\
\hline 2014 & 7.886 .152 & 2.024 .973 & 3,8944 \\
\hline \multicolumn{3}{|c|}{$\begin{array}{c}\text { Rata-Rata Sebelum Akuisisi (2012- } \\
\text { 2014) }\end{array}$} & 1,3046 \\
\hline 2015 & -1.513 .714 & 1.062 .980 & $-1,4240$ \\
\hline 2016 & -1.587 .310 & 1.308 .250 & $-1,2133$ \\
\hline 2017 & -1.494 .888 & 982.463 & $-1,5216$ \\
\hline \multicolumn{3}{|c|}{$\begin{array}{c}\text { Rata-Rata Sesudah Akuisisi (2015- } \\
\text { 2017) }\end{array}$} & $-1,3863$ \\
\hline
\end{tabular}

Sumber: Laporan Keuangan PT First Media, Tbk

Copyright (C) 2019, FINANCIAL: Jurnal Akuntansi
(Data Diolah), 2019

Dari Tabel 8 dapat dilihat bahwa nilai rata-rata Net Profit Margin (NPM) sebelum akuisisi adalah sebesar 1,3046 kali dan mengalami penurunan sesudah akuisisi sebesar 2,6909 kali menjadi -1,3863 kali. Kondisi ini menunjukkan bahwa kinerja keuangan perusahaan lebih baik sebelum perusahaan melakukan akuisisi. Nilai ratarata Net Profit Margin (NPM) sesudah akuisisi mengalami penurunan dari nilai rata-rata Net Profit Margin (NPM) sesudah akuisisi. Penurunan ini disebabkan oleh kerugian yang dialami perusahaan diikuti dengan menurunnya pendapatan perusahaan. Beban layanan dan beban keuangan mengalami peningkatan yang cukup signifikan, namun pendapatan perusahaan menurun. Hal ini mengakibatkan perusahaan mengalami kerugian sesudah akuisisi.

\section{SIMPULAN DAN SARAN}

Simpulan dari penelitian ini adalah nilai Current Ratio (CR) sebelum dan sesudah akuisisi cenderung berfluktuasi dan mengalami penurunan pada PT First Media, Tbk yang terdaftar di Bursa Efek Indonesia periode 2012-2017. Kondisi ini menunjukkan bahwa kinerja keuangan perusahaan lebih baik sesudah perusahaan melakukan akuisisi. Nilai rata-rata Debt Ratio (DR) dan DER sesudah akuisisi mengalami peningkatan dari nilai rata-rata Debt Ratio (DR) dan nilai rata-rata DER sebelum akuisisi. Kondisi ini menunjukkan bahwa kinerja keuangan perusahaan lebih baik sebelum perusahaan melakukan akuisisi.

Nilai Total Asset Turnover (TATO) sebelum dan sesudah akuisisi mengalami fluktuasi dan cenderung meningkat pada PT First Media, Tbk yang terdaftar di Bursa 
Efek Indonesia periode 2012-2017. Kondisi ini menunjukkan bahwa kinerja keuangan perusahaan lebih baik sesudah perusahaan melakukan akuisisi. Nilai rata-rata Return on Equity (ROE), Return on Asset (ROA), dan Net Profit Margin (NPM) mengalami penurunan sesudah akuisisi. Kondisi ini menunjukkan bahwa kinerja keuangan perusahaan lebih baik sebelum perusahaan melakukan akuisisi.

Saran yang dapat diberikan penulis adalah sebaiknya PT First Media, Tbk. sebaiknya perusahaan mengoptimalkan pengelolaan aset melalui penambahan persediaan sesuai dengan kondisi yang dibutuhkan, sehingga siklus penjualan dapat lebih cepat dan pendapatan meningkat. Dengan meningkatnya pendapatan diharapkan dapat membayar seluruh hutang baik hutang jangka pendek maupun hutang jangka panjang. Untuk peneliti selanjutnya dapat menambah tahun penelitian atau menambah objek penelitian agar hasil penelitian dapat digeneralisir.

\section{DAFTAR PUSTAKA}

Aprilita, Ira, Rina Tjandrakirana DP, dan H. Aspahani. (2013). Analisis Laporan Keuangan Untuk Menilai Kinerja Keuangan Pada PT BPR Citra Dumago Manado. Jurnal Manajemen dan Bisnis vol.11 no.2 Juni 2013, hal. 100-114.

Brigham, Eugene F. dan Joel F. Houston. 2010. Dasar-Dasar Manajemen Keuangan. Edisi 11. Jakarta: Salemba Empat.

Https://www.kompasiana.com/yolandaamal ia3944/5ceb9918aa3ccd733428cb7d/a pakah-indonesia-sudah-memasukiera-revolusi-industri-4-0?page $=$ all. Diakses pada tanggal 9 Desember 2019 pukul 09.00 WIB.

Melindhar, Suristika. (2015). Analisis Kinerja Keuangan Sebelum dan Sesudah Akuisisi Menggunakan
Analisis Rasio Keuangan pada Perusahaan Go Public yang Terdaftar di BEI (Periode Tahun 2009-2014). Jurnal Ilmiah Mahasiswa FEB Universitas Brawijaya vol.3 no.2, hal. 1-18.

Moin. (2010). Merger, Akuisisi, dan Divestasi. Yogyakarta: Ekonisia.

Mursyidi. (2010). Akuntansi Dasar. Bogor: Ghalia Indonesia.

Novaliza, Putri dan Atik Djajanti. (2013). Analisis Pengaruh Merger dan Akuisisi Terhadap Kinerja Perusahaan Publik Di Indonesia (Periode 2004 - 2011). Jurnal Akuntansi dan Bisnis vol.1 no.1 September 2013.

Ottay, Maikel Ch. (2015). Analisis Laporan Keuangan Untuk Menilai Kinerja Keuangan Pada PT BPR Citra Dumago Manado. Jurnal EMBA vol.3 no.1 Maret 2015, hal. 923-932.

Pongoh, Marsel. (2013). Analisis Laporan Keuangan Untuk Menilai Kinerja Keuangan PT Bumi Resources, Tbk. Jurnal EMBA vol.1 no.3 September 2013, hal. 669-679.

Ramadhan, Kurnia Dewi dan La Ode Syarfan. (2016). Analisis Laporan Keuangan Dalam Mengukur Kinerja Keuangan Pada PT Ricky Kurniawan Kerta Persada (Makin Group) Jambi. Jurnal Valuta vol.2 no.2 Oktober 2016, hal.190-207.

Rudianto. (2012). Pengantar Akuntansi, Konsep dan Teknik Penyusunan Laporan Keuangan, Adaptasi IFRS. Jakarta: Erlangga.

Setiawan, Irwan Amdani. (2013). Analisis Rasio Keuangan Untuk Mengukur Kinerja Keuangan PT Indocement Tunggal Prakarsa, Tbk Sebelum dan Sesudah Akuisisi Periode 2007 2011. Jurnal Administrasi Bisnis (JAB) vol.2 no. 1 Mei 2013.

\section{PROFIL SINGKAT}

Nur Safitri, lahir di Pematangsiantar, pada tanggal 12 Februari tahun 1998. Baru saja 
menyelesaikan pendidikan Sarjana Ekonomi pada Program Studi Akuntansi di STIE Sultan Agung pada tahun 2019. Supitriyani, lahir di Pematangsiantar pada tanggal 16 Mei tahun 1988. Menyelesaikan pendidikan Magister pada Program Studi Ilmu Akuntansi di Universitas Sumatera Utara pada tahun 2013. Saat ini beliau beraktivitas sebagai Dosen Tetap di STIE Sultan Agung. Debi Eka Putri, lahir di Pematangsiantar pada tanggal 03 Agustus 1993. Menyelesaikan pendidikan Magister pada Program Studi Manajemen Keuangan di Universitas Muhammadiyah Sumatera Utara pada tahun 2017. Saat ini beliau beraktivitas sebagai Dosen Tetap di STIE Sultan Agung. Khairul Azwar lahir di Karang Bangun pada tanggal 12 Oktober 1986. Menyelesaikan pendidikan Magister pada Program Studi Akuntansi Manajemen di Universitas Muhammadiyah Sumatera Utara pada tahun 2017. Saat ini beliau beraktivitas sebagai Dosen Tetap di STIE Sultan Agung. 